\title{
Hubungan Pengetahuan Kesehatan Gigi dan Mulut dengan Status Kesehatan Gingiva pada Penyandang Tunanetra di Panti Tunanetra Manado
}

\author{
${ }^{1}$ Christy Mintjelungan, ${ }^{2}$ Elita Tambunan, ${ }^{3}$ Shinta Takahindangen \\ ${ }^{1}$ Program Studi Kedokteran Gigi, Fakultas Kedokteran Universitas Sam Ratulangi \\ ${ }^{2}$ Dinas Kesehatan Kota Manado \\ ${ }^{3}$ Mahasiswa Program Studi Kedokteran Gigi \\ Fakultas Kedokteran Universitas Sam Ratulangi
}

\begin{abstract}
ABSTRAK
Pengetahuan tentang kesehatan gigi dan mulut sangat penting untuk terbentuknya tindakan menjaga kesehatan gigi dan mulut. Pengetahuan dapat diperoleh antara lain melalui indra penglihatan. Penyandang tunanetra memiliki keterbatasan dalam penglihatan yang memengaruhi kemampuan dalam memperoleh pengetahuan dan memengaruhi tindakan menjaga kesehatan gigi dan mulut mereka. Penyandang tunanetra beresiko tinggi mengalami masalah kesehatan gigi dan mulut sehingga berdampak pula pada status kesehatan gingiva mereka. Tujuan dari penelitian ini ialah untuk mengetahui hubungan pengetahuan kesehatan gigi dan mulut dengan status kesehatan gingiva pada penyandang tunanetra di panti tunanetra Manado.

Penelitian ini merupakan penelitian deskriptif analitik dengan pendekatan cross-sectional study. Data diperoleh dengan menggunakan kuesioner dan pemeriksaan status kesehatan gingiva menggunakan Modifikasi Indeks Gingiva. Data diperoleh dari 39 responden pada kelompok usia 11-40 tahun dengan menggunakan teknik total sampling. Data disajikan dalam bentuk tabel distribusi frekuensi. Hasil penelitian menunjukan tidak ada hubungan bermakna antara pengetahuan kesehatan gigi dan mulut dengan status kesehatan gingiva $(p=0,614)$.
\end{abstract}

Kata kunci : pengetahuan kesehatan gigi dan mulut, tunanetra, status kesehatan gingiva

\begin{abstract}
Knowledge of dental health are important for the formation of action in oral health behaviour. Knowledge can be obtained, among others, through the sense of sight. Visually impaired people have limited vision that affects the ability to acquire knowledge and influence the action to maintain their oral health. They are at high risk for oral health problems that impact the gingival status. The aim of this study was to determine the correlation between dental health knowledge with gingival status in visually impaired people in Residence for visually impaired people in Manado. This study is a descriptive analytic study using a cross-sectional design. Dental health knowledge were assessed using the questionnaire and their gingival status was measured by Modified Gingival Index. Data obtained from 39 respondents in the age group 1140 years by using the total sampling. Data presented in the form of a frequency distribution table. The results of study showed that there was no statistically significant correlation between oral health knowledge and gingival status $(p=0.614)$.
\end{abstract}

Keywords : dental knowledge, visually impaired, gingival status

Korespondensi: Shinta L. Takahindangen, Program Studi kedokteran Gigi, Fakultas Kedokteran Universitas Sam Ratulangi, Manado, Indonesia. E-mail: shintatakahindangen@gmail.com

\section{PENDAHULUAN}

Penyakit gigi dan mulut termasuk penyakit periodontal, masih banyak diderita oleh penduduk di Indonesia. ${ }^{1}$ Berdasarkan data Riset Kesehatan Dasar tahun 2007, prevalensi nasional masalah gigi dan mulut mencapai $23,5 \%$. Sebanyak 19 provinsi di Indonesia mempunyai prevalensi masalah gigi dan mulut di atas prevalensi nasional. Sulawesi Utara merupakan salah satu dari lima provinsi yang memiliki prevalensi masalah gigi dan mulut tertinggi yaitu sebesar $29,8 \%{ }^{2}$ 
Salah satu yang dapat memengaruhi derajat kesehatan seseorang yaitu perilaku. Menurut Notoatmodjo, domain perilaku kesehatan terbagi atas tiga yaitu pengetahuan, sikap, dan tindakan. Pengetahuan merupakan domain yang sangat penting untuk terbentuknya tindakan seseorang. Pengetahuan terjadi setelah orang melakukan pengindraan terhadap suatu objek tertentu, salah satunya melalui indra penglihatan. ${ }^{3}$

Indra penglihatan merupakan salah satu elemen penting dalam mendapatkan pengetahuan. Tunanetra adalah istilah umum yang digunakan untuk kondisi seseorang yang mengalami gangguan atau hambatan dalam indra penglihatannya. ${ }^{4}$ Berdasarkan data World Health Organization (WHO) tahun 2010, diperkirakan jumlah penduduk dengan gangguan penglihatan sebanyak 285 juta penduduk, yaitu 39 juta penduduk buta total dan 246 juta memiliki low vision. ${ }^{5}$

Keterbatasan dalam penglihatan yang dimiliki oleh penyandang tunanetra memengaruhi kemampuan mereka dalam memperoleh pengetahuan, termasuk pengetahuan kesehatan gigi dan mulut. Hal ini mengakibatkan peyandang tunanetra kurang optimal dalam menjaga kesehatan rongga mulutnya. Beberapa penelitian membuktikan bahwa penyandang tunanetra (buta maupun low vision) memiliki status kesehatan gigi dan mulut yang rendah. ${ }^{6,7,8}$ Penyandang tunanetra mempunyai risiko yang lebih tinggi mengalami penyakit gigi dan mulut, yaitu penyakit periodontal. ${ }^{9}$ Dalam penelitian yang dilakukan oleh Jinan Mohammed, didapatkan bahwa Indeks Gingiva pada penyandang tunanetra lebih tinggi daripada orang normal. ${ }^{10}$

Berdasarkan survey awal yang dilakukan penulis di panti tunanetra yang ada di Manado yaitu Panti Sosial Bina Netra (PSBN) Tumou Tou dan Panti Sosial Tunanetra (PST) Bartemeus Gereja Masehi Injili di Minahasa (GMIM), didapatkan data jumlah penyandang tunanetra yang ada di kedua panti tersebut berjumlah 59 orang. Belum pernah dilakukan penelitian tentang kesehatan gigi dan mulut di kedua panti tersebut.
Berdasarkan uraian di atas, penulis tertarik untuk mengadakan penelitian mengenai hubungan pengetahuan tentang kesehatan gigi dan mulut dengan status kesehatan gingiva pada penyandang tunanetra di panti tunanetra Manado.

\section{BAHAN DAN METODE}

Penelitian ini merupakan penelitian deskriptif analitik dengan menggunakan rancangan penelitian potong lintang (crosssectional study). Penelitian dilakukan di PSBN Tumou Tou dan PST Bartemeus GMIM Manado pada bulan AgustusSeptember 2013. Populasi dalam penelitian ini ialah semua penyandang tunanetra berusia 11 tahun ke atas yang berjumlah 39 orang dengan teknik pengambilan sampel yang digunakan yaitu total sampling.

Pengumpulan data diperoleh melalui kuesioner pengetahuan kesehatan gigi dan mulut dan pemeriksaan status kesehatan gingiva dengan menggunakan Modifikasi Indeks Gingiva. Dibacakan informed consent bagi responden untuk dimintai persetujuan, responden diwawancara secara langsung untuk menjawab pertanyaan dalam kuesioner, dan dilakukan pemeriksaan status kesehatan gingiva dengan Modifikasi Indeks Gingiva. Data diolah dan disajikan dalam bentuk tabel. Analisa data dengan menggunakan analisa univariat dan bivariat.

\section{HASIL PENELITIAN}

Tabel 1. Distribusi responden berdasarkan jenis kelamin.

\begin{tabular}{lcc}
\hline $\begin{array}{c}\text { Jenis } \\
\text { Kelamin }\end{array}$ & Jumlah (n) & Persentase (\%) \\
\hline Laki-laki & 23 & 59 \\
Perempuan & 16 & 41 \\
\hline Total & 39 & 100 \\
\hline
\end{tabular}


Tabel 2. Distribusi responden menurut usia

\begin{tabular}{ccc}
\hline $\begin{array}{c}\text { Usia } \\
\text { (Tahun) }\end{array}$ & Jumlah (n) & $\begin{array}{c}\text { Persentase } \\
(\%)\end{array}$ \\
\hline $11-20$ & 20 & 51,3 \\
$21-30$ & 14 & 35,9 \\
$31-40$ & 5 & 12,8 \\
\hline Total & 39 & 100 \\
\hline
\end{tabular}

Tabel 3. Distribusi pengetahuan responden

\begin{tabular}{ccc}
\hline Pengetahuan & $\begin{array}{c}\text { Jumlah } \\
(\mathrm{n})\end{array}$ & Persentase(\%) \\
\hline Baik & 32 & 82,1 \\
Kurang & 7 & 17,9 \\
\hline Total & 39 & 100 \\
\hline
\end{tabular}

Tabel 4. Distribusi peradangan gingiva responden

\begin{tabular}{ccc}
\hline Peradangan & Jumlah (n) & Persentase (\%) \\
\hline Ada & 38 & 97,4 \\
Tidak ada & 1 & 2,6 \\
\hline Total & 39 & 100 \\
\hline
\end{tabular}

Tabel 5. Hubungan pengetahuan kesehatan gigi dan mulut dengan status kesehatan gingiva responden

\begin{tabular}{ccccccccc}
\hline & \multicolumn{4}{c}{ Peradangan } & & \\
\cline { 2 - 5 } Kategori & \multicolumn{3}{c}{ Ada } & \multicolumn{2}{c}{ Tidak } & \multicolumn{2}{c}{ Total } \\
Pengetahuan & $\mathrm{n}$ & $\%$ & $\mathrm{n}$ & $\%$ & $\mathrm{n}$ & $\%$ \\
\hline & & & & & & & \\
Baik & 31 & 96,9 & 1 & 3,1 & 32 & 100 \\
& & & & & & \\
Kurang & 7 & 100 & 0 & 0 & 7 & 100 \\
\hline & & & & & & \\
Total & 38 & 97,4 & 1 & 2,6 & 39 & 100 \\
\hline
\end{tabular}

\section{PEMBAHASAN}

Responden dalam penelitian ini berjumlah 39 responden, sebagian besar berjenis kelamin laki-laki dengan jumlah 23 orang (51\%), sedangkan responden berjenis kelamin perempuan sebanyak 16 orang (49\%). Hal ini sama dengan penelitian yang dilakukan oleh Mohammad Sami Ahmad pada tahun 2009 mengenai pengetahuan dan praktik kesehatan gigi dan mulut serta prevalensi status kesehatan gigi dan mulut pada penyandang tunanetra di Aligarh yang melibatkan 80 responden yang terdiri dari 55 responden $(68,7 \%)$ berjenis kelamin laki-laki. ${ }^{6}$ Hal ini berbeda dengan data global WHO yang menyatakan lebih banyak penyandang tunanetra berjenis kelamin perempuan dibandingkan lakilaki. ${ }^{5}$ Berdasarkan usia responden yang diteliti, sebagian besar responden pada kelompok usia 11 - 20 tahun sebanyak 20 orang $(51,3 \%)$, dan yang paling sedikit pada kelompok usia 31 - 40 tahun sebanyak 5 orang $(21,8 \%)$.

Dari hasil penelitian yang dilakukan, pengetahuan responden terbanyak dengan jumlah 32 responden $(82,1 \%)$ tergolong dalam kategori baik, sedangkan responden dengan pengetahuan kurang berjumlah 7 responden (17,9\%). Lebih dari sebagian penyandang tunanetra dalam penelitian ini memiliki pengetahuan baik. Hal ini berbeda dengan penelitian yang dilakukan ChienHuey pada tahun 2004 mengenai pengetahuan kesehatan gigi dan mulut dan praktik kebersihan mulut pada siswa tunanetra dan siswa normal di Taiwan yang menyatakan bahwa penyandang tunanetra memiliki pengetahuan kesehatan gigi dan mulut yang masih kurang. ${ }^{11}$ Hasil penelitian yang berbeda ini disebabkan karena usia responden yang berbeda pada kedua penelitian ini. Pada penelitian yang dilakukan oleh Chien-Huey, responden penelitian berusia 6 - 18 tahun, sedangkan pada penelitian ini rentang usianya mulai dari $11 \quad-40$ tahun. Usia berpengaruh terhadap daya tangkap dan pola pikir seseorang. Semakin bertambah usia akan semakin berkembang pula daya tangkap 
dan pola pikirnya, sehingga pengetahuan yang diperolehnya semakin membaik..$^{12,13}$ Faktor lingkungan juga dapat berpengaruh pada hasil yang berbeda dalam penelitian ini. Lingkungan berpengaruh terhadap proses masuknya pengetahuan ke dalam individu yang berada dalam lingkungan tersebut. $^{12}$ Perbedaan lingkungan berpengaruh pada pengetahuan yang diterima penyandang tunanetra.

Berdasarkan pemeriksaan status kesehatan gingiva yang dilakukan dengan menggunakan MIG, responden dengan kriteria gingiva sehat berjumlah 1 responden $(3,1 \%)$ dan responden dengan kriteria peradangan ringan dan sedang berjumlah sebanyak 38 responden (96,9\%). Dari hasil penelitian di atas, diketahui bahwa hampir seluruh responden mengalami peradangan pada gingiva, namun terdapat 1 responden yang memiliki gingiva sehat. Hal ini sama dengan penelitian yang dilakukan oleh Jinan Mohammed pada tahun 2009 mengenai status kesehatan gigi dan kebutuhan perawatan pada tunanetra di Irak didapatkan bahwa penyandang tunanetra memiliki nilai indeks gingiva yang lebih tinggi daripada orang normal. ${ }^{10}$ Penyandang tunanetra berisiko mengalami masalah kesehatan gigi dan mulut termasuk peradangan gingiva karena mengalami kesulitan dan keterbatasan dalam memelihara kesehatan gigi dan mulut mereka. Penyandang tunanetra tidak dapat melihat dan membersihkan sisa makanan yang menempel pada gigi mereka dengan benar. Selain itu, penyandang tunanetra tidak dapat mendeteksi dan mengenali penyakit gigi dan mulut sedini mungkin serta tidak dapat segera mengambil tindakan apabila tidak ada pihak yang memberitahukan kepada mereka. ${ }^{9,10}$ Hasil penelitian yang dilakukan oleh Rokkiah Omar, dkk pada tahun 2010 mengenai praktik menjaga kesehatan gigi dan mulut dan status periodontal pada penyandang tunanetra pada anak tunanetra di Irak juga ditemukan bahwa peradangan gingiva merupakan masalah kesehatan gigi dan mulut yang utama pada penyandang tunanetra. ${ }^{9}$ Peradangan gingiva pada penyandang tunanetra dipengaruhi oleh tindakan pemeliharaan kesehatan gigi dan mulut mereka. Kurangnya tindakan pemeliharaan kesehatan gigi dan mulut penyandang tunanetra menyebabkan mereka memiliki status kebersihan mulut yang kurang pula. Pada penelitian yang dilakukan oleh Scardina mengenai penilaian dan promosi kesehatan gigi dan mulut pada penyandang tunanetra tahun 2007 dan penelitian yang dilakukan oleh Reddy pada tahun 2011 mengenai prevalensi status kesehatan gigi dan mulut pada penyandang tunanetra didapatkan bahwa status kebersihan mulut penyandang tunanetra dalam kondisi buruk. ${ }^{7,8}$ Kebersihan gigi dan mulut penyandang tunanetra yang masih kurang menjadikan resiko mereka untuk mengalami peradangan gingiva semakin tinggi.

Responden dengan pengetahuan baik dan tidak memiliki peradangan (-) hanya 1 orang $(3,1 \%)$. Pengetahuan seseorang tentang suatu obyek mengandung dua aspek yaitu aspek positif dan aspek negatif. Kedua aspek inilah yang akhirnya akan menentukan sikap seseorang terhadap objek tertentu. Semakin banyak aspek positif dari obyek yang diketahui, akan menumbuhkan sikap semakin positif terhadap obyek tersebut. ${ }^{12}$ Pada penelitian ini dapat dilihat bahwa hanya 1 responden yang memberikan respon positif terhadap pengetahuan yang diterimanya. Artinya, pengetahuan yang baik mengenai kesehatan gigi dan mulut, menumbuhkan sikap dan tindakan pemeliharaan kesehatan gigi dan mulut yang baik pula. Responden dengan pengetahuan baik yang memiliki peradangan gingiva berjumlah 31 responden $(96,9 \%)$. Pengetahuan yang dimiliki responden tidak memiliki pengaruh bagi status kesehatan gingivanya. Pengetahuan baik yang dimilikinya tidak direspon secara positif oleh responden menjadi suatu sikap dan tindakan pemeliharaan kesehatan gigi dan mulut, sehingga peradangan gingiva pada responden dengan kategori pengetahuan baik masih sangat tinggi. Responden memiliki pengetahuan baik, namun tidak diikuti dengan tindakan pemeliharaan kesehatan gigi dan mulut yang baik pula. Hal ini serupa dengan penelitian yang 
dilakukan oleh Heriyanto Yonan pada tahun 2004 mengenai hubungan antara pengetahuan, persepsi dan sikap terhadap kesehatan gigi dengan status kesehatan gigi pada siswa tunanetra di PSBN Wyata Bandung. Dalam penelitian ini juga didapatkan bahwa pengetahuan tidak memiliki hubungan yang bermakna terhadap gingivitis pada penyandang tunanetra $(p=0,273){ }^{14}$ Sebagian besar responden memiliki pengetahuan mengenai kesehatan gigi dan mulut dalam kategori baik, namun hampir seluruh responden memiliki peradangan gingiva. Pengetahuan merupakan domain yang sangat penting untuk terbentuknya tindakan seseorang (overt behavior). Tingkatan pengetahuan seseorang terdiri dari tahu, memahami, aplikasi, analisis, sintesis dan evaluasi. ${ }^{3}$ Namun pada penelitian ini, pengetahuan tidak memberikan pengaruh secara signifikan terhadap status kesehatan gingiva responden. Pengetahuan responden pada penelitian ini hanya sampai pada tingkatan "tahu", namun pengetahuannya tidak diaplikasikan dalam tindakan mereka. Meskipun responden memiliki pengetahuan yang baik mengenai kesehatan gigi dan mulut, tetapi belum tentu mereka memiliki tindakan yang baik terhadap pemeliharaan kesehatan gigi dan mulut sehingga didapatkan hampir seluruh penyandang tunanetra di panti tunanetra Manado memiliki peradangan gingiva.

\section{SIMPULAN}

Berdasarkan hasil penelitian dan pembahasan, maka dapat disimpulkan bahwa responden yang memiliki pengetahuan baik sebanyak 32 orang $(82,1 \%)$. Responden yang memiliki peradangan gingiva sebanyak 38 responden dan responden yang tidak memiliki peradangan gingiva hanya 1 responden serta tidak terdapat hubungan bermakna antara pengetahuan kesehatan gigi dan mulut dengan status kesehatan gingiva pada penyandang tunanetra di Panti Tunanetra Manado.

\section{SARAN}

Disarankan kepada Dinas Kesehatan dan Dinas Sosial Kota Manado untuk lebih meningkatkan kegiatan pemeliharaan kesehatan gigi dan mulut penyandang tunanetra, misalnya pemeriksaan gigi dan mulut serta pelatihan pemeliharaan kesehatan gigi dan mulut. Diharapkan juga kepada peneliti lainnya untuk dapat melakukan penelitian lebih lanjut dengan cakupan yang lebih beragam, sehingga hasilnya dapat digunakan secara umum untuk pengembangan kesehatan gigi dan mulut.

\section{DAFTAR PUSTAKA}

1. Putri M, Herijulianti E, Nurjannah N. Ilmu Pencegahan Penyakit Jaringan Keras Dan Jaringan Pendukung Gigi. Jakarta: Buku Kedokteran EGC. 2011; h. 1, 26-38, 196-198.

2. Badan Penelitian dan Pengembangan Kesehatan Departemen Kesehatan. Riset Kesehatan Dasar 2007. Available from:

http://www.litbang.depkes.go.id/bl_risk esdas2007 [ Cited 2013 Apr 17 ]

3. Notoadmodjo S. Kesehatan Masyarakat Ilmu dan Seni. Jakarta: Rineka Cipta. 2011; h. 146-150.

4. Anonim. Pengertian Tunanetra. Available from: http://id.wikipedia.org/wiki/Tunanetra [Cited 2013 Apr 17]

5. Mariotti Silvio. Global Data on Visual Impairments 2010. Available from:http://www.who.int/blindness/GL OBALDATAFINALforweb.pdf [Cited 2013 Apr 17]

6. Ahmad M, Jindal M, Khan S, Hashmi S. Oral Health Knowledge,Practice, oral hygiene status and dental caries prevalence among visually impaired students in resedential institute of Aligarh.Journal of dentistry and Oral hygiene [serial online] June 2009 [Cited 2013 Apr 17];1(2). Available from:http://www.academicjournals.org/ jdoh/PDF/Pdf2009/Aug/Ahmad\%20et \%20al.pdf 
7. KVKK $\mathrm{R}$,A Sharma .Prevalence of Oral health status in visually impared children . Journal of Indian Society of Periodontics and Preventive Dentistry [serial online] Jan-Mar 2011 [Cited 2013 Apr 17]; 29 (1). Available from: http://www.jisppd.com/temp/JIndianSo cPedodPrevDent29125-

3503162_094351.pdf ;

8. Scardina G, Buonamente A, Carini F, Messina P. Appraisal and Promotion of Oral health in a Group of Visually Impaired Patient .Research Journal of Biologic Sciences [serial online] 2007 [Cited 2013 Apr 17 ] ; 2 (3): 365-8. Available from:http://docsdrive.com/pdfs/medwel ljournals/rjbsci/2007/365-368.pdf

9. Omar R, Malik N, Saiman K, Rahmat N. Self Reported Oral hygiene Practices and Periodontal Status of Visually Impaired Adults .Global Journal of Health Sciece [serial online] Oktober 2010 [Cited 2013 Apr 17 ] ; 2 (2): 18491. Available from: http://www.ccsenet.org/journal/index.p hp/gihs/article/download/5737/5896

10. Al-Alousi J.Oral Health Status and Treatment Needs among Blind Children in Iraq.Oral Health Status and Treatment Needs among Blind [serial online] 2009 [Cited 2013 Apr 17]; 6 (4): 313-24. Available from http://www.iasj.net/iasj?func=fulltext \& $\underline{\mathrm{aId}=31862}$

11. Chang C, Shih Y . Knowledge of Dental Health and Oral Hygiene Practices of Taiwanese Visually Impaired and Sighted Student.Journal of Visually Impaired and Blindness [serial online] 2004 May [Cited 2013 Apr 22 ] ;98 (5). Available from: http://www.eric.ed.gov/PDFS/EJ68351 $\underline{\text { 5.pdf }}$

12. Anonim. Faktor-faktor yang mempengaruhi pengetahuan. Available from: http://duniabaca.com/definisipengetahuan-serta-faktor-faktor-yangmempengaruhi-pengetahuan.html [Cited 2013 Apr 17]

13. Wawan A, M Dewi. Teori dan Pengukuran Pengetahuan, Sikap, dan
Perilaku Manusia Dilengkapi Contoh Kuesioner.Yogyakarta:Nuha Medika.2010;h.18.

14. Yonan, Heriyanto.Hubungan antara Pengetahuan, Persepsi dan Sikap terhadap Kesehatan Gigi dengan Status Kesehatan Gigi pada Siswa Tunanetra di Panti Sosial Bina Netra (PSBN) Wyata Guna Bandung [serial online] 2004 May [Cited 2013 Apr 22]. Available from: http://etd.ugm.ac.id 